2020, Volume 14, International Conference Innovative Business Management \& Global Entrepreneurship (IBMAGE 2020), pages: 414-425 |

https://doi.org/10.18662/lumproc/ibmage2020/30

\section{Integration of Generation $\mathrm{Z}$ in the Professional Environment}

\section{Iulia MANGHIUC1, Ciprian PETRESCU²}

1 "Valahia" University, Târgovişte, Doctoral School of Economics and Humanities, Management Field, Bucharest, Romania, juliam 21@yahoo.com

2 "Valahia" University, Târgovişte, Doctoral School of Economics and Humanities, Management Field, Bucharest, Romania, petrescucipri@yahoo.com
Abstract: This study highlights the assimilation of generation $\mathrm{Z}$ in the professional environment and its adaptation to the requirements of the organization it is part of.

The candidates who have advanced knowledge in the field of technology are the target audience that will generate personalized education over time, but also interesting opportunities, who are growing in an environment relying only on technology and will be much more flexible in thinking and decision making, being those who grew up online. Born during the digital age, they will prefer an independent brand at the expense of a traditional / experienced brand.

The intersection method used by combining the quantitative and qualitative approach will seek to identify the components of an effective professional integration system.

The results obtained also highlight the fact that this process plays a key role in creating a convenient environment where the members of generation $\mathrm{Z}$ can explore their native creativity.

The whole integration process will consist of a series of challenges that organizations will be facing in attracting and keeping the members of this generation, but also of methods used for its capitalization.

The conclusions highlight the importance of this reference process for any member of Generation Z.

Keywords: integration, generation Z, professional environment, creativity, organization.

How to cite: Manghiuc, I., \& Petrescu, C. (2020). Integration of Generation Z in the Professional Environment. In M. W. Staniewski, V. Vasile, \& A. Grigorescu (vol. ed.), Lumen Proceedings: Vol. 14. International Conference Innovative Business Management \& Global Entrepreneurship (IBMAGE 2020) (pp. 414-425). Iasi, Romania: LUMEN Publishing House. https://doi.org/10.18662/lumproc/ibmage2020/30 


\section{Introduction}

Boomers, Gen X, Millennials, Gen Z and Gen Alpha are some of the generations that coexist in the professional environment, and the voice of Generation $Z$ is becoming more and more heard lately. Numerically superior ${ }^{1}[2]$, as compared to other generations, they show their native creativity, without being stimulated by employers, they only need a convenient environment and sometimes the framework to support them. The opportunities offered will increase so that this generation can make its presence felt.

The article intends to highlight the characteristics of this generation, the organizational environment where they will be integrated, the investigations regarding aspects related to their capabilities, but also the results that the organization will register.

Our benchmark will be the challenges of organizations in attracting and keeping the generation, how can I overcome them?

And at the end we will identify the behavioural characteristics of the Generation $Z$, the values and preferences at their job which they emphasize, but also the need of individuals to integrate into the professional environment and maintain their ability to perform in today's environment.

\section{Problem Statement}

In the current context, Generation $Z$ includes individuals who are between 14 and 23 years old, and the professional environment is only at the beginning of the absorption of this generation. Starting from the premise that not much is known about Gen $Z$ yet, but only about the environment in which they will develop: very diverse, highly technological, for the individuals of this generation the year 2020 is considered to be just the end of maturity, and according to a study by Sparks and Honey [17] - cultural consultants, it was found that $60 \%$ of Gen $Z$ members say they want to change the world, as compared to $39 \%$ of Millennials.

Against the background of this debut and in the context in which this generation is only in the phase of detailed study by marketers, we can say that the scientific literature has a gap, and researchers in the field undertake various studies and are still monitoring the evolution of this phenomenon.

\footnotetext{
1 According to data of the National Institute of Statistics, there are over 3.6 million representatives of generation $Z$, and according to a study published by the United Nations last year, the share of this generation represented $32 \%$ of the world's 7.7 billion population.
} 
The research intends to highlight the ability of young people in Gen $Z$ to integrate into the professional environment, but also the adaptive ability of employers to create the professional environment that keeps those employees and enhance their skills.

\section{Research Questions/Aims of the research}

Starting from the questions that underlie this scientific approach, the main objectives of this research are the following:

- identification of the characteristics of Generation $Z$ in relation to the other age categories;

- identification of the characteristics of the organizational environment in which those from Gen $Z$ will be integrated, as well as the results that the organization will register;

- identification of the needs of individuals to integrate into the professional environment and to maintain their performance ability in the current environment.

\section{Research Methods}

In our research approach we used the qualitative method where the observation and analysis of documents / data were our main tools.

For this topic, this year in June-July we undertook a study conducted on a sample of 121 subjects from Bucharest - Ilfov aged between 18-35 years, students, employees, employers from institutions / organizations, from the public and private sector.

The research was conducted based on the interview and aimed to identify the perceptions, attitudes and behaviours of potential employees and employers in relation to social relations at work.

\section{Findings}

It is necessary for any educational and professional fair and not only, to create a platform / a consulting office that initiates adolescents / young people aged between 18 and 35 to be consulted by mentors so as to be able to create an image that reproduces reality exactly, about What does it mean to have a job? The opportunity to have access to online platforms has been an asset from the beginning, given the need for employers to identify and respond to the needs of the younger generation, as well as the continuous, accurate, complete and relevant nature of these supports, based on the latest pieces of information [15]. 
The new generation employability kit involves that reference element designed to meet the requirements of the target group, stating that the employer will use this tool in terms of strategic objectives assumed and over time, they will be required to meet these objectives with the people they have recruited and selected. It would be preferable for this package not to have a promotional or standard character [18].

An intense concern arose when international investors made their presence felt on the labour market. This process has led to real competition, as well as to the increased interest in setting up specialized services in recruiting and selecting staff, but in particular it has required special attention to the structure of the employability package presented to potential employees.

From the perspective of companies, there is a top 5 of the characteristics that define a perfect job, and these are the following: the opportunity to develop their career, teamwork, an ostentatious job, flexibility and passion [10].

This study aims to identify those components necessary for an employability kit when the target group is represented by those who do not believe in perfection and reject perfection, since they are those who adopt the practical spirit, who accept reality, seeking to individualize and be independent, different from Generation $Y$ that throughout its era sought mentoring and impeccable and even perfect services.

Brands that want to address them must make use of the transition from digital adaptation to digital native, and moreover, they are the ones who will not appreciate a traditional / experienced brand, but will prefer to be independent and to be constantly exposed to innovation [20].

The purpose of this paper is to identify the components of the package that will meet the requirements of Generation $Z$, but that will also help to meet the performance objectives at the strategic level [22].

The offer of a job fair has a global impact, and the message sent through interstitials or advertisements brings to the fore as the only employment opportunity. Thus, any career fair comes with several key points regarding: the interaction with $n$ companies, among the most coveted industries; $n$ jobs, thousands of jobs, dedicated to both students and professional juniors; career counselling from human resources specialists; at the fair there is an area of $C V$ Experts, divided into areas: Scoring, 0 experiences, Your Destination, Professional Reconversion, First Interview, PhotoHotel, Career Workshops that offer the opportunity to participate in various professional and personal development sessions; those working in the IT field can find out the latest trends by participating in TechTalks sessions. 
However, the stake of the requirement that any fair launches, already held and / or acquired, is the professional training, either initial or continuous, at any of the stages.

In comparison with the other generations (see Table 1 - Types of generations), there are over 3.6 million representatives of Gen $Z$ globally and according to a study published by the United Nations last year, the share of this generation accounted for $32 \%$ of the world's 7,7 billion population. They are those who were born in the period 1995-2012, the period of maturity is between 2013-2020, and their current age is between 14-23 years.

The specialized literature is only at the beginning of the study because this generation is only in its early stage. We still don't know much about them, but we know more about the environment in which they develop. They have exposed themselves in an age of technology, which in turn will provide them with more and more opportunities. Studies state that in comparison with those in Gen $Y$, they will be more flexible, they refuse promises for a perfect life. If the previous generation needed mentoring, the current generation needs independence and seeks to assert their personality.

If the oldest member of the generation is about 21-23 years old, it seems that marketers are only now studying them. If the Millennials saw there could be a gain from a collaboration, they are much more individualistic. Technology no longer fascinates them so much, they consider it a tool to which they have access from anywhere. They build their own brands, and consider the traditional ones as a point of support, but do not define them. They filter the information very selectively, they do not need excessive conviction, it was found that if the brand fails to transmit information or to capture their attention in maximum 8 seconds, they refuse any collaboration. [9].

They are pragmatic when it comes to traditional brands, and their financial resources are valuable, they emphasize the quality-price ratio.

In terms of social relations, they have a small number of members in the group to which they belong and do not seem interested in the other representatives of Gen $Z$.

They are not subject to gender, religion or affiliation prejudices. They are more and more feminist, both boys and girls and they consider that they can work and hold the same type of job, either boy or girl.

The organizational environment in which those of this generation will be integrated seems to be the only known element from this equation. As we have mentioned, it is a diverse environment, until now, it is the period when technology is at its peak and which in turn will offer more and more opportunities to those who will use it. 
Table 1. Types of generations

\section{Year of birth / \\ Maturity}

Boomers I

Baby Boomers

[19]

$\bullet 1946-1954$

$\bullet 1963-1972$

- Boomers II/ Jones Generation

- Generation X

- $1955-1965$

- $1973-1983$

- 1966-1976

Generation Y, Echo Boomers or Millennials

Generation Z

Alpha

- 1966-1976

- 1988-1994

- $1995-2012$

- 2013-2020

from 2010 (it may last even 15 years)

- 1988-1994 the decree" that had to endure the most changes

They are a challenge for marketers and the most desired segment of the population.

They are more united as a generation and more willing to make their voices heard [13]

These are those who grew up online.

They don't believe in ideals.

They look for independence and personalization.

It is supposed to be the most educated generation

We will hear about them in 10 years.

- 2020-2035

Source: adaptation after [4] 
It seems that these young people only need a suitable environment, they already come with a baggage of excessive creativity, acquired natively, so employers do not have to stimulate it, but only have to provide them with a framework and opportunities and to learn from those in Gen $Z$ how to approach things their way.

In order to attract and keep them, employers will have to pay attention to the preferences and needs of generations, especially since those in Generation $Z$ are already in the field of work, and most organizations have employees of all ages. Employers will need to pay more and more attention to the differences between them so as to have them work for them.

One of the other challenges employers are facing is how to recruit and select them. In principle, the ads follow the classic model, a lot of text, but, as we have mentioned, those in Gen $Z$ have an attention span of 8 seconds. In this fraction, they are already making a decision: whether it is worth investing their trust and time $[12 ; 6]$.

Specialists in the field believe that the branch must be performed and adapted to the generation, so that job ads convey creativity, attractiveness, visual message, focused on the values and contribution that the individual man can have. This generation is one that emphasizes authenticity, creativity, personal contribution. For them, the fact that the values and mission of a company are exposed is not enough, but the way they are translated into concrete actions determines them to choose one company to the detriment of another.

In order to recruit them, the employer will have to promote an authentic brand, based on a story with a current employee. Also, Corporate Social Responsibility actions with the company's field of activity and with the causes that employees choose to join (promoting a cause, marketing related to a cause, social marketing, philanthropic actions, community volunteering, socially responsible business practices), all presented in a natural style, not to sound like a self-praise [5].

When we talk about keeping them, employees will stay if they feel involved and capitalized [7], if they are given personalized and diversified tasks, if they will receive feedback, such as instant gratification.

The new evaluation models that large companies apply and record major results with are those of employee engagement and empowering.

Another internal approach that the company will have to adopt is to give employees confidence in the flexibility of the program and in obtaining the results related to the deadlines and standards set, not to a fixed program monitored by a supervisor. 
The National Institute of Statistics states that the representatives of generation $\mathrm{Z}$ are over 3.6 million, and according to a study published by the United Nations last year, the share of this generation accounted for $32 \%$ of the world's 7.7 billion population.

According to Catalyst [1] - a company with over 13 years of experience in the field of recruitment that has conducted a study in MarchMay 2019 on a sample of over 18,000 respondents with a business, engineering and pharma profile. The aim of the study was to discover the perceptions of the candidates in relation to the employers in Romania. Thus, hey intended to measure the level of attractiveness of employers on the local market. In the top of the most coveted private companies there were companies in the field of IT, sales and communications.

In the study, the factors from 4 main categories were evaluated: reputation; work environment; salary package and career advancement opportunities; professional development opportunities and job characteristics of an employer.

Also, following our analysis focusing on the professional orientations of the generation in the field of employments, preferences were identified, especially in the IT field, but high values were also recorded in the case of institutions in the defense, public order and national security system. Thus, $37 \%$ of respondents say they would be interested in pursuing a career in this system. However, they claim to be uninterested in self-employment, instead they are interested in finance and $82 \%$ want financial stability.

We would like to discuss a little about the register of employers and mention that, unlike any of the top employers participating in various fairs, either locally, at the City of Jobs, or online at the Virtual Top Employers, the military system is the component of a body that is subject to the same rules or even restrictions, but which has a special system of rules on marketing [21].

The Ministry of National Defense has an immense capacity to provide education in its own structures (military education and vocational training institutions at initial and continuous level) during a university / school year, is a national top employer. It reaches over 5,500 places annually, from high school to university education, doctoral studies, with / without attendance, with funds secured from the budget / for a tuition, both for its own ministry and for other structures in the same system, and, under the conditions of promotion, its goal is to distribute people on positions ${ }^{2}$ [14].

\footnotetext{
2 The schooling plan in the military education institutions / units and in the initial and continuous vocational training structures for the academic year / school year 2019-2020.
} 
Out of the total schooling figure mentioned above, the Ministry of National Defense has approximately 5,200 places, which it can capitalize on annually. The soldiers thus trained are the main basis for the distribution on positions and the quantitative and qualitative assurance of qualified personnel.

Thus, the activity of promoting the military profession in a job fair aims to support the recruitment of human resources necessary to fulfil the missions and objectives of the military institution, bringing a substantial contribution to the image of the military profession, as well as to the increase of the educational and professional offer attractiveness of the Ministry of National Defense for the target audience in civilian and military circles, using appropriate methods and means of communication.

The major objectives in such a promotion campaign are to ensure a constant and sufficiently large flow of candidates, with an aptitudemotivational profile appropriate to the requirements of the military profession, throughout the recruitment period, increasing the level of information of audiences and the correct and timely target audience information, but also gaining and maintaining the interest (loyalty) of potential candidates [11].

In such a campaign, the target audience is represented by candidates aged between 13-50 years, but also the support group consisting of parents, friends, teachers, etc.

Also, certain organizational entities within the Ministry are directly involved, being responsible for this field of activity ${ }^{3}$.

In principle, the promotion campaign has at least 3 mandatory components: the direct component, the advertising and information component and the public relations component which in turn involve certain activities.

The direct component involves a direct approach to the target audience by distributing promotional materials in the recruitment environments; more precisely, the presentation of the professional and educational offer of the Ministry, the direct information and counselling, the organization of meetings between civilian students with young military or students of Military Colleges, the organization of documentation visits in military units or educational institutions, maintaining permanent contact with potential candidates (email / social media pages), as well as participation in educational and professional offers fairs.

\footnotetext{
${ }^{3}$ General Directorate of Human Resources Management, Information and Public Relations Directorate, Zonal / County / Sector Military Centers through Information Offices Recruitment, military units / educational institutions
} 
The advertising component is supported by non / media advertising media, audio / video broadcasting advertising spots, online / outdoor / indoor advertising.

And the third component is distinguished by the organization of special events (information and promotion stands, the Army - a different school, Cadet for one day, Summer Camp for Scouts), as well as by public actions (briefings and press releases, radio / video broadcasts of the talk-show type, interviews in the written press, media coverage of military students with outstanding results and military with successful careers and outstanding performances, social networking sites and pages and the internal information of the Ministry's staff).

The range of locations for such events is quite wide from the online environment, to military / civilian educational units / institutions, to public places intensely frequented by a large and diverse audience (stations, airports, means of common transportation), fairs with educational and professional offers.

Returning to our study, we mention that based on the results obtained, as well as on those from Catalyst, we noticed that famous brands are preferred by future employees, especially those with a history. It should be noted that a fairly high percentage of subjects want financial security, but not on their own, for the moment. As we have already mentioned, money is precious to them, and people at Catalyst say that this generation is less open to access a study loan; and the number of those involved has been declining since 2009.

\section{Conclusions}

We believe that Gen $Z$ will have the ability to demand greater customization throughout their careers. For organizations to attract and keep the best and smartest employees of the generation, they will need a different mindset.

Employers must be prepared to adopt a pace of evolution that suits the external environment if they want to attract Gen Z. This means developing strong training and leadership programs with a real and tangible emphasis on diversity [3].

Thus, companies will need to develop the profile of an excellent employee, establish internships, invest in smart and talented employees and then assign them a well-defined role in the organization [16].

The evolution of generations will not stop here until 2025, when the next generation - Alpha generation will account for 2 billion people globally [8], they will be the richest, the most educated and the most experienced in 
terms of technology throughout history, says Robert Hannah, operational director at Grant Thornton UK [8].

\section{References}

[1] CATALYST. The Most Desired Employers Survey [Internet]. București: Catalyst.ro; 2019 [cited 2020 August 4]. Available from: https://www.catalyst.ro/project/the-most-desired-employers-the-employerbranding-survey-in-romania/

[2] Cornea R. Cum se comportă angajaţii din Generația Z pe piaţa muncii. Cei din generația nouă sunt flexibili, dar mai puțin organizați, fac repede schimbări şi vor feedback constant: companiile nu îi înțeleg [Internet]. Bucureşti: Ziarul Financiar; 17.02.2020 [ cited 2020 July 6]. Available from: https://www.zf.ro/zf-24/cum-se-comporta-angajatii-din-generatia-z-pepiata-muncii-cei-din-generatia-noua-sunt-flexibili-dar-mai-putin-organizatifac-repede-schimbari-si-vor-feedback-constant-companiile-nu-ii-inteleg$\underline{18850952}$

[3] Corey S, Meghan G. Generation Z Leads: A Guide for Developing the Leadership Capacity of Generation Z Students. United States of America: CreateSpace Independent Publishing Platform; 2017. 92 p.

[4] Costa D. Generațiiile de pe piața muncii şi angajabilitatea [Internet]. ClujNapoca: Today Software Magazine; 25.08.2016 [ cited 2020 August 4]. Available from: https://www.todaysoftmag.ro/article/2052/generatiile-depe-piata-muncii-si-angajabilitatea

[5] Dorsey J, Villa D. Zconomy: How Gen Z Will Change the Future of Business - and What to Do About It. United States of America: Harper Business; Illustrated Edition; 2020. 288 p.

[6] Elmore T, McPeak A. Generation Z Unfiltered: Facing Nine Hidden Challenges of the Most Anxious Population. Atlanta, Georgia: Poet Gardener; 2019. 336 p.

[7] Fromm J, Read A. Marketing to Gen Z: The Rules for Reaching This Vast and Very Different Generation of Influencers. Special Edition. New York: AMACOM; 2018. 224 p.

[8] Hannah R. Generation Alpha: The Children of the Millennial [Internet]. Interesting Engineering; 18.12.2018 [cited 2020 July 12]. Available from: https:/ / interestingengineering.com/generation-alpha-the-children-of-themillennial

[9] Hobart J, Sendek H. Generatia Y. Generatia mileniului 3 si evolutia leadershipului. . Bucharest: BMI; 2017. 259 p. 
[10] Iosip F. Târgul de job-uri, Angajatori de TOP, revine în Bucureşti în perioada 26-27 octombrie. Peste 130 de companii vor fi prezente [Internet]. Bucureşti: Adevarul; 10.10.2018[cited 2020 March 31]. Available from: https://adevarul.ro/news/societate/targul-job-uri-angajatori-top-revinebucuresti-perioada-26-27-octombrie-130-companii-vor-prezente1 5bbde6f0df52022f755eca74/index.html

[11] Jenkins R. The Generation Z Guide: The Complete Manual to Understand, Recruit, and Lead the Next Generation. Atlanta: Ryan Jenkins, LLC, 2019. 378 p.

[12] Jenkins R. Gen Z: The Culture, Beliefs and Motivations Shaping the Next Generation. Atlanta: Barna Group, 2018. 128 p.

[13] Masback G. The Voice of GEN Z: Understanding the Attitudes \& Attributes of America's Next „Greatest Generation”. United States of America: CreateSpace Independent Publishing Platform; 2016. 110 pages.

[14] Ministerul Apararii Nationale. Direcția generală management resurse umane [nternet]. Bucureşti: MAPN; 2020 [cited 2020 May 22]. Available from: https://dmru.mapn.ro/

[15] Pescaru C. Generația Z, într-o relație complicată cu angajatoriii? [Internet]. Revista Cariere; 27.06.2019 [cited 2020 May 4]. Available from: https://revistacariere.ro/leadership/piata-muncii-employment/generatia-zintr-o-relatie-complicata-cu-angajatorii/

[16] Shahi R. The Z Factor: How to Lead Gen Z to Workplace Success. United States of America: New Degree Press; 2019. 186.

[17] Sparks \& Honey. Gen Z [Internet]. United States of America: SparksandHoney.com; 2020 [cited 2020 May 22]. Available from: https://www.sparksandhoney.com/gen-z

[18] Stillman D, Stillman J. Gen Z @ Work: How the Next Generation Is Transforming the Workplace. United States of America: Harper Business; 2017. 320 p.

[19] Tocilă C. Care sunt Generațiile X, Y şi Z şi ce urmează după ele? [Internet]. Claudiatociala.ro; 22.01.2015 [cited 2020 June 25]. Available from: http://claudiatocila.ro/generatiile/

[20] Valkenburg P, Piotrowski J. Generația digitală şi dependența de media. Bucureşti: Editura Niculescu; 2017. 328 p.

[21] Weise S. InstaBrain: The New Rules for Marketing to Generation Z. United States of America: Independently published; 2019. 236 p.

[22] White E. J. Meet Generation Z: Understanding And Reaching The New Post-Christian World. United States of America: Baker Books; 2017. 224 p. 